\title{
Inoculation of Arbuscular Mycorrhizal Fungi Increase the Growth of Cocoa and Coffee Seedling Applied with Ayamaru Phosphate Rock
}

\author{
Antonius Suparno ${ }^{1}$, Saraswati Prabawardani ${ }^{2}$, Sudirman Yahya ${ }^{3} \&$ Novita A. Taroreh $^{4}$ \\ ${ }^{1}$ Department of Agriculture, Faculty of Agriculture and Technology, The University of Papua (UNIPA), \\ Manokwari, Indonesia \\ ${ }^{2}$ Agronomy Laboratory, Faculty of Agriculture and Technology, The University of Papua (UNIPA), Manokwari, \\ Indonesia \\ ${ }^{3}$ Department of Agronomy, Faculty of Agriculture, Bogor Agriculture Institute (IPB), Bogor, Indonesia \\ ${ }^{4}$ Department of English Literature, Faculty of Letters The University of Papua (UNIPA), Manokwari Papua \\ Barat, Indonesia \\ Correspondence: Antonius Suparno, Department of Agriculture, Faculty of Agriculture and Technology, The \\ University of Papua (UNIPA), Manokwari, Indonesia. Tel: 62-853-5488-7556. E-mail: anton.sprn@gmail.com
}

Received: February 24, 2015 Accepted: March 25, 2015 Online Published: April 15, 2015

doi:10.5539/jas.v7n5p199 URL: http://dx.doi.org/10.5539/jas.v7n5p199

\begin{abstract}
Researh was carried out aimed to study the response of cocoa and coffee seedlings inoculated by Arbuscular Mycorrhizal Fungi (AMF) and applied with Ayamaru Phosphate Rock (APR). The research was cunducted at Bogor Agriculture Institute (IPB) and Papua University (Unipa) Manokwari Indonesia. Cocoa seed (Upper Amazone Hybrid F-1) and Arabica coffee seed (Coffea arabica) were collected from the Indonesian Coffee and Cocoa Research Institute (ICCI) Jember Indonesia. Cocoa dan coffee seedling were planted in polybag with acid soil medium, under $60 \%$ shading net. Cocoa and coffee seedlings were grown for 16 weeks after planting. AMF inoculum used Mycofer that was collected from IPB consisted of four species i.e Gigaspora margarita (INVAM-105), Glomus etunicatum (NPI-126), (Acaulospora tuberculata (INDO-2), Glomus manihotis (INDO-1) and indigenous AMF Manokwari consisted of three species i.e A. tuberculata Janos \& Trappe, A. scrobiculata Trappe, and G. aggregatum Schenck \& Smith. Ayamaru Phosphate Rock (APR) was collected from Ayamaru District, West Papua, Indonesia. The result showed that the growth of cocoa seedling applied with APR up to $4 \mathrm{~g}$ $\mathrm{P}_{2} \mathrm{O}_{5} \cdot$ seedling $^{-1}$ and the growth of coffee seedling applied with APR up to $8 \mathrm{~g} \mathrm{P}_{2} \mathrm{O}_{5} \cdot$ seedling $^{-1}$ increased linearly. Compared to control (without AMF), inoculation of AMF Mycofer increased the cocoa seedling's height up to $50.58 \%$ and shoot dry-weight $127.55 \%$, whereas height of coffee seedling increased by $27.29 \%$ and shoot dry-weight by $121.21 \%$. For all APR dosage, the growth of cocoa and coffee seedling inoculated with AMF Mycofer inoculum was better than inoculated by indigenous AMF and without AMF (control).
\end{abstract}

Keywords: cocoa, coffee, mycorrhiza, phosphate rock, seedling

\section{Introduction}

Arbuscular Mycorrhiza Fungi (AMF) is widely known to have an important role in improving growth, yield, and quality of agriculture plants, horticulture, plantation, forestry, recovering land degradation and stabilizing upland ecosystem (Vosátka \& Albrechtová, 2009; Gianinazzi et al., 2010).

Association between AMF and plant root was formed by the obligate fungi system with approximately $80-90 \%$ of upland plants (Wang \& Qui, 2006) or approximately $73 \%$ of flowering plant family (Brundrett, 2009), both those that have root and without root (Read et al., 2000; Pressel et al., 2010), and they also have mutualism characteristic which covering $83 \%$ of dicotyledone and $79 \%$ of monocotyledone (Swift, 2004).

Swift (2004) states that one of the several significant responses of AMF infection on host plant is the increase of $\mathrm{P}$ uptake that mainly due to the capability of AMF to absorb $\mathrm{P}$ from soil and transfer it to the host plant roots. When the plant is in deficiency of $\mathrm{P}$ or $\mathrm{N}$, this symbiotic association will be advantage and improve plant growth (Morgan et al., 2005).

Cocoa and coffee are perennial plants that are able to symbiotic with AMF to improve their plant growth. 
Miyakasa and Habte (2001) state that cocoa and coffee are depend highly on symbiotic with AMF. Mutualism symbiotic between AMF and plants is beneficial for plants in enhancing growth and yield, improving plant vitality, and increasing minerals absorbtion area by root plants, due to smaller diameter of AMF hyphae than hair diameter of plant root (Sylvia, 2005).

Generally, great number of high quality seedlings are expected by seedling producer. High quality seedlings produced by breeding or genetic selection, culture technic, planting method, and accurate plant management will determine the success of seedling growth in the field (van den Driessche, 1994; South, 2000; Carneiro et al., 2007), particularly at marginal lands. Marginal lands are generally acid soil which $\mathrm{P}$ is bounded by $\mathrm{Fe}$ and $\mathrm{Al}$. This causes unavailability of $\mathrm{P}$ to plant and reduces plant growth. Cocoa and coffee are perennial plants, therefore the effectiveness of AMF inoculation can be more optimal if the inoculation process was done in the seedling period and as a result when transferred to the field, plants will grow and yield better.

Cacao and coffee are exported commodities which generate high economic income, and these commodities have been broadly cultivated. Therefore, researh was carried out to study the growth of cocoa and coffee seedlings in response to the inoculation of Arbuscular Mycorrhizal Fungi (AMF) and applied with Ayamaru Phosphate Rock (APR). Effective AMF will produce good quality of cacao and coffee seedlings and this will increase fertilizer efficiency.

\section{Materials and Methods}

The experiment was carried out in 2009 at Cikabayan University Farm, IPB Bogor, Indonesia and at Unipa's Green House in 2012. The plant material was Hybrid cocoa seedling F-1 Upper Amazone Hibrid (UAH) and Arabica coffee collected from the Indonesian Coffee and Cocoa Research Institute (ICCRI) in Jember, East Java. Growing media was the acid soil with $\mathrm{Al}_{\mathrm{dd}} 17.03 \mathrm{cmol} \cdot \mathrm{kg}^{-1}$. APR which was obtained from Ayamaru District, West Papua Indonesia.

The plantlets were grown for four months under $60 \%$ shading net. The experiment was set up in a Completely Randomized Design. For cocoa seedling trial, the first factor was AMF inoculation, consisted of none AMF (mo), indigenous AMF from cocoa rhizosphere Manokwari $\left(\mathrm{m}_{1}\right)$, and Mycofer from IPB Bogor $\left(\mathrm{m}_{2}\right)$; the second factor was five dosages of APR 0, 0.5, 1.0, 1.5, and $2.0 \mathrm{~g} \mathrm{P}_{2} \mathrm{O}_{5}$ 'seedling ${ }^{-1}$, with $2.0 \mathrm{~g} \mathrm{P}_{2} \mathrm{O}_{5}$ SP-36.seedling ${ }^{-1}$ was as a comparison. For coffee seedling trial, the first factor was AMF inoculation, consisted of none AMF (mo), indigenous AMF from cocoa rhizosphere Manokwari $\left(\mathrm{m}_{1}\right)$, and Mycofer from IPB Bogor $\left(\mathrm{m}_{2}\right)$; the second factor was five dosages of APR 0, 2, 4, 6, and $8 \mathrm{~g} \mathrm{P}_{2} \mathrm{O}_{5} \cdot$ seedling ${ }^{-1}$, with $2.0 \mathrm{~g} \mathrm{P}_{2} \mathrm{O}_{5}$ SP-18.seedling ${ }^{-1}$ was as a comparison.

The experiment was conducted three times by using $20 \mathrm{~cm} \times 30 \mathrm{~cm}$ sized polybag which was filled with $3 \mathrm{~kg}$ soil. Each seed was grown in each polybag with three polybags for each experimental unit.

The inoculum production was done by Sorghum bicolor band zeolit as a growing media. The inoculum consisted of propagule which was a mixture of spore, infected root, hyphal and growing media. After Most Probable Number test, each plant was inoculated by 10 grams inoculum.

The observed variables were growth of seedlings, shoot dry-weight, leaf number, seedling height, stem diameter, root dry-weight, shoot-root ratio, shoot $P$ uptake, root colonization, and the effectiveness of AMF inoculum.

Root colonization is measured by the following formula:

$$
\text { Root colonization }(\%)=\frac{\text { number of infected roots }}{\text { number of observed roots }} \times 100 \%
$$

The effectiveness of AMF inoculum is measured by formula:

$$
\text { The AMF effectiveness (\%) }=\frac{\text { Mycorrhyza Plant }- \text { Non Mycorrhyza Plant }}{\text { Mycorrhyza Plant }} \times 100 \%
$$

P uptake was measured by:

$$
\text { Shoot } P \text { uptake }=\text { Shoot } P \text { content } \times \text { shoot dry weight }
$$

The data of the experimental result was analysed by using Analysis of Variance, and followed by LSD test if the treatment showed a significant effect. LSD test was used to compare the effect of AMF between APR and SP-36 application. The effect of APR dosages levels to the growth of cocoa and coffea seedling was analysed by regression correlation analysis. All the data were analysed using SAS v 9.0 software.

\section{Result and Discussion}

Cocoa and coffee belong to perennial plant that depend highly on symbiotic with AMF. AMF inoculation and APR application increased growth of both of cocoa and coffee seedlings. As the application level of APR dosage 
increased the seedling growth also increased at all APR dosage levels. AMF inoculation produced better response on the growth of cocoa and coffee seedling (Tables 1 and 3). AMF Mycofer was more effective to increase the growth of cocoa and coffee seedling if compared to seedling without AMF and seedling inoculated by indigenous AMF (Figures 1 and 3).

Table 1. Seedling height, stem diameter, roots dry-weight, and shoot-root ratio of cocoa seedling resulted from AMF inoculation in several levels of APR dosages

\begin{tabular}{|c|c|c|c|c|}
\hline Treatment & Seedling Height $(\mathrm{cm})$ & Stem Diameter (mm) & Root Dry-Weight $\left(\mathrm{g} \cdot\right.$ seedling $\left.^{-1}\right)$ & Shoot-root Ratio \\
\hline \multicolumn{5}{|c|}{ APR dosage $\left(\mathrm{g} \mathrm{P}_{2} \mathrm{O}_{5} \cdot\right.$ seedling $\left.{ }^{-1}\right)$ : } \\
\hline \multicolumn{5}{|l|}{ Control: } \\
\hline 0 & $32.48 \mathrm{~b}$ & $6.15 \mathrm{c}$ & $1.32 \mathrm{c}$ & $2.57 \mathrm{~d}$ \\
\hline 0.5 & $34.83 \mathrm{ab}$ & $6.41 \mathrm{bc}$ & $1.43 \mathrm{bc}$ & $3.05 \mathrm{bc}$ \\
\hline 1.0 & $36.39 \mathrm{a}$ & $6.58 \mathrm{ab}$ & $1.59 \mathrm{abc}$ & $3.01 \mathrm{c}$ \\
\hline 1.5 & $37.00 \mathrm{a}$ & $6.85 \mathrm{a}$ & $1.75 \mathrm{a}$ & $3.07 \mathrm{bc}$ \\
\hline 2.0 & $38.56 \mathrm{a}$ & $6.92 \mathrm{a}$ & $1.64 \mathrm{ab}$ & $3.47 \mathrm{~b}$ \\
\hline SP-36: 2.0 g P$_{2} \mathrm{O}_{5} \cdot$ seedling $^{-1}$ & $38.06 \mathrm{a}$ & $6.97 \mathrm{a}$ & $1.68 \mathrm{ab}$ & $3.90 \mathrm{a}$ \\
\hline LSD Test (95\%) & 3.93 & 0.49 & 0.29 & 0.42 \\
\hline \multicolumn{5}{|l|}{ AMF Inoculum: } \\
\hline $\mathrm{m}_{0}$ & $27.21 \mathrm{C}$ & $5.69 \mathrm{C}$ & $1.01 \mathrm{C}$ & $3.01 \mathrm{~A}$ \\
\hline $\mathrm{m}_{1}$ & $38.00 \mathrm{~B}$ & $6.93 \mathrm{~B}$ & $1.69 \mathrm{~B}$ & $3.21 \mathrm{~A}$ \\
\hline $\mathrm{m}_{2}$ & $43.15 \mathrm{~A}$ & $7.26 \mathrm{~A}$ & $2.01 \mathrm{~A}$ & $3.31 \mathrm{~A}$ \\
\hline \multicolumn{5}{|l|}{ Effectiveness (\%) : } \\
\hline $\mathrm{m}_{1} \mathrm{vs} \mathrm{m}_{0}$ & 39.65 & 21.79 & 67.33 & 6.64 \\
\hline $\mathrm{m}_{2} \mathrm{vs} \mathrm{m}_{1}$ & 13.55 & 4.76 & 18.93 & 3.12 \\
\hline $\mathrm{m}_{2}$ vs $\mathrm{m}_{0}$ & 58.58 & 27.59 & 99.01 & 9.96 \\
\hline
\end{tabular}

Note. The number in one column followed by the same letter is not significantly different in LSD Test for $95 \% . \mathrm{m}_{0}$ : non AMF; $\mathrm{m}_{1}$ : Manokwari indigenous AMF; $\mathrm{m}_{2}$ : Mycofer AMF; vs: versus.
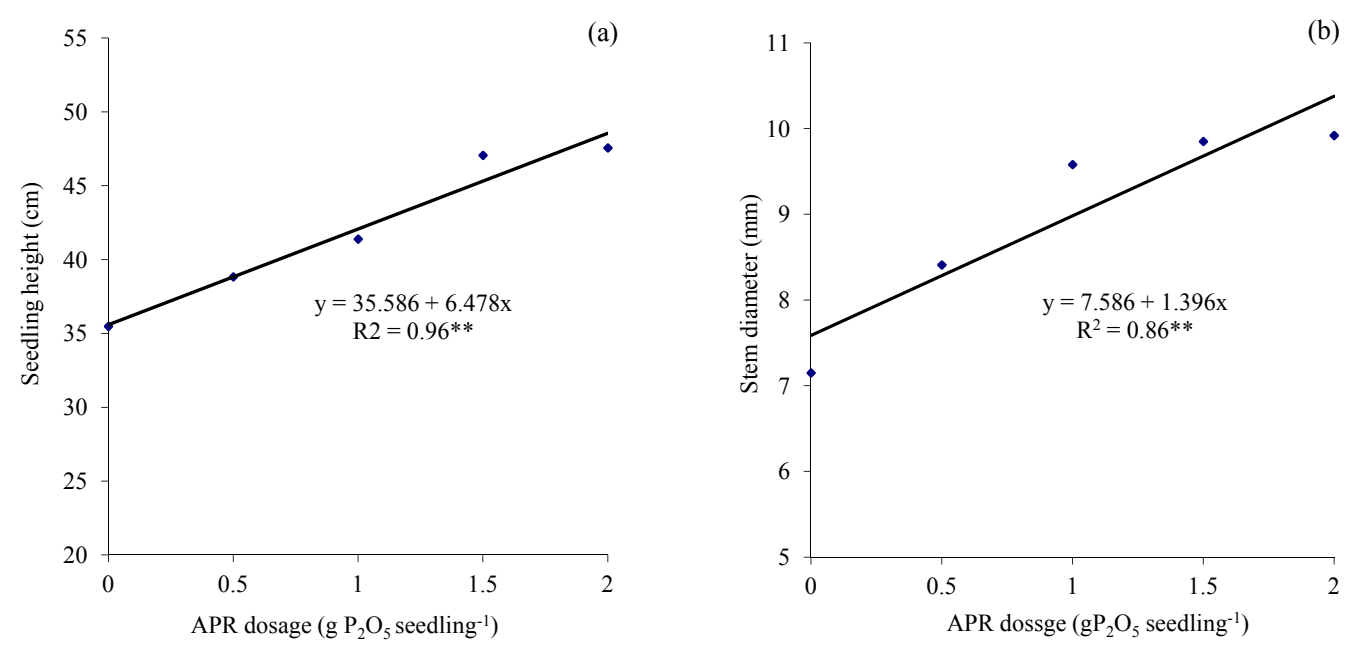
(c)

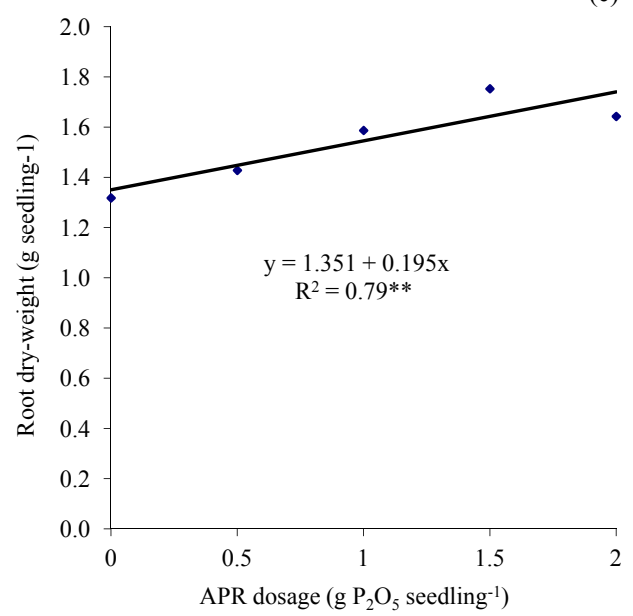

Figure 1. The relationship of seedling height (a), stem diameter (b), and root dry-wight (c) of cocoa seedlings to APR dosage levels

Note. ${ }^{*}$ : highly significant; *: significant.

Table 2. Response of shoot dry-weight response, shoot $\mathrm{P}$ uptake, root colonization, and acid phosphatase activity of cocoa seedling to APR dosage at different AMF inoculums

\begin{tabular}{|c|c|c|c|c|c|c|c|}
\hline \multirow{2}{*}{ Treatment } & \multicolumn{5}{|c|}{ APR dosage $\left(\mathrm{g} \mathrm{P}_{2} \mathrm{O}_{5} \cdot\right.$ seedling $\left.{ }^{-1}\right)$} & \multirow{2}{*}{ SP-36 } & \multirow{2}{*}{ Curve Response } \\
\hline & 0 & 0.5 & 1.0 & 1.5 & 2.0 & & \\
\hline & \multicolumn{6}{|c|}{ 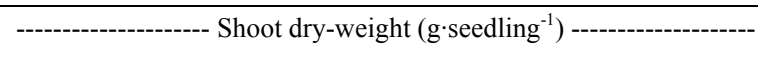 } & \\
\hline $\mathrm{m}_{0}$ & 1.68 & 2.74 & 2.93 & 3.40 & 3.23 & 3.88 & Linear \\
\hline $\mathrm{m}_{1}$ & 3.62 & 4.70 & 5.24 & 4.70 & 6.33 & 7.82 & Linear \\
\hline $\mathrm{m}_{2}$ & 4.98 & 5.55 & 6.33 & 7.09 & 7.35 & 7.85 & Linear \\
\hline \multicolumn{8}{|c|}{ Effectiveness (\%): } \\
\hline $\mathrm{m}_{1}$ vs $\mathrm{m}_{0}$ & 115.48 & 71.53 & 78.84 & 38.23 & 95.97 & 101.55 & \\
\hline $\mathrm{m}_{2} \mathrm{vs} \mathrm{m}_{0}$ & 196.43 & 102.55 & 116.04 & 108.53 & 127.55 & 102.32 & \\
\hline \multirow[t]{2}{*}{$\mathrm{m}_{2} \mathrm{vs} \mathrm{m}_{1}$} & 37.57 & 18.09 & 20.80 & 50.85 & 16.11 & 0.0030 & \\
\hline & \multicolumn{6}{|c|}{ 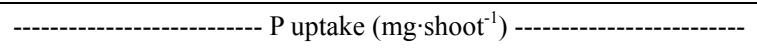 } & \\
\hline $\mathrm{m}_{0}$ & 3.50 & 4.30 & 5.85 & 6.85 & 7.75 & 8.20 & Linear \\
\hline $\mathrm{m}_{1}$ & 5.50 & 6.50 & 7.05 & 8.35 & 9.40 & 13.60 & Linear \\
\hline $\mathrm{m}_{2}$ & 7.60 & 8.20 & 9.90 & 10.85 & 11.25 & 13.70 & Linear \\
\hline \multicolumn{8}{|c|}{ Effectiveness (\%): } \\
\hline $\mathrm{m}_{1} \mathrm{vs} \mathrm{m}_{0}$ & 57.14 & 51.16 & 20.51 & 21.90 & 21.29 & 65.85 & \\
\hline $\mathrm{m}_{2}$ vs $\mathrm{m}_{0}$ & 117.14 & 90.70 & 69.23 & 58.39 & 45.16 & 67.07 & \\
\hline \multirow[t]{2}{*}{$\mathrm{m}_{2}$ vs $\mathrm{m}_{1}$} & 38.18 & 26.15 & 40.43 & 29.94 & 19.68 & 0.007 & \\
\hline & \multicolumn{7}{|c|}{-------------------- Root colonization (\%) ----------------- } \\
\hline $\mathrm{m}_{0}$ & 10.00 & 13.33 & 6.67 & 10.00 & 6.67 & 3.33 & Quadratic \\
\hline $\mathrm{m}_{1}$ & 73.33 & 73.33 & 86.67 & 93.33 & 96.67 & 13.33 & Linear \\
\hline $\mathrm{m}_{2}$ & 86.67 & 90.00 & 93.33 & 100.00 & 100.00 & 16.67 & Linear \\
\hline \multicolumn{8}{|c|}{ Effectiveness (\%): } \\
\hline $\mathrm{m}_{1}$ vs $\mathrm{m}_{0}$ & 633.30 & 450.11 & 1199.40 & 833.30 & 1349.33 & 300.30 & \\
\hline $\mathrm{m}_{2}$ vs $\mathrm{m}_{0}$ & 766.70 & 575.17 & 1299.25 & 900.00 & 1399.25 & 400.60 & \\
\hline $\mathrm{m}_{2} \mathrm{vs} \mathrm{m}_{1}$ & 18.19 & 22.73 & 7.68 & 7.15 & 3.44 & 25.06 & \\
\hline
\end{tabular}




\begin{tabular}{|c|c|c|c|c|c|c|c|}
\hline \multirow[b]{2}{*}{$\mathrm{m}_{0}$} & \multicolumn{6}{|c|}{----------- Acid phosphatase activity $\left(\mu \mathrm{g} \cdot \mathrm{g}^{-1} \cdot \mathrm{hour}^{-1}\right)$----------- } & \multirow[b]{2}{*}{ Quadratic } \\
\hline & 1.44 & 3.47 & 4.12 & 3.30 & 3.34 & 2.33 & \\
\hline $\mathrm{m}_{1}$ & 3.49 & 5.45 & 4.84 & 5.45 & 3.69 & 3.56 & Linear \\
\hline $\mathrm{m}_{2}$ & 3.59 & 5.52 & 6.54 & 5.46 & 5.68 & 5.16 & Linear \\
\hline \multicolumn{8}{|c|}{ Effectiveness (\%): } \\
\hline $\mathrm{m}_{1}$ vs $\mathrm{m}_{0}$ & 142.36 & 57.06 & 17.48 & 65.15 & 10.48 & 52.79 & \\
\hline $\mathrm{m}_{2}$ vs $\mathrm{m}_{0}$ & 149.31 & 59.08 & 58.73 & 65.45 & 70.06 & 121.46 & \\
\hline $\mathrm{m}_{2}$ vs $\mathrm{m}_{1}$ & 2.87 & 1.28 & 35.12 & 0.18 & 53.93 & 44.94 & \\
\hline
\end{tabular}
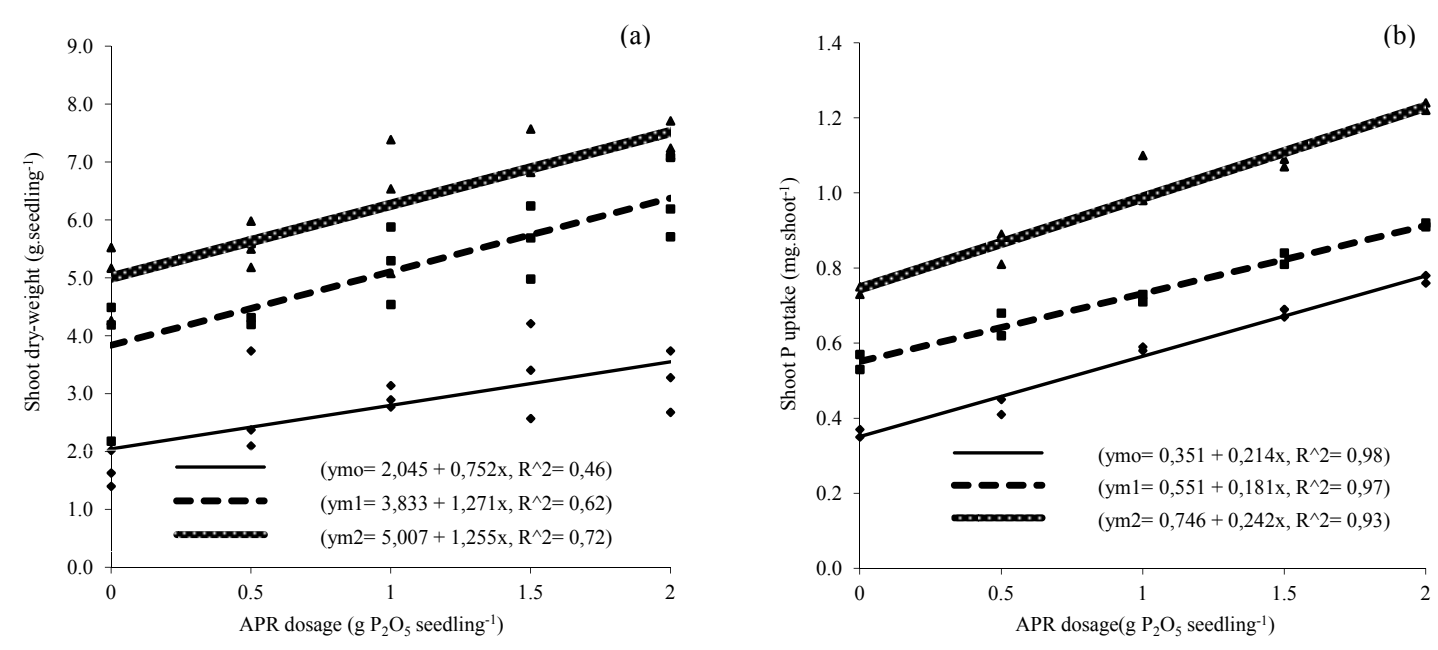

(c)
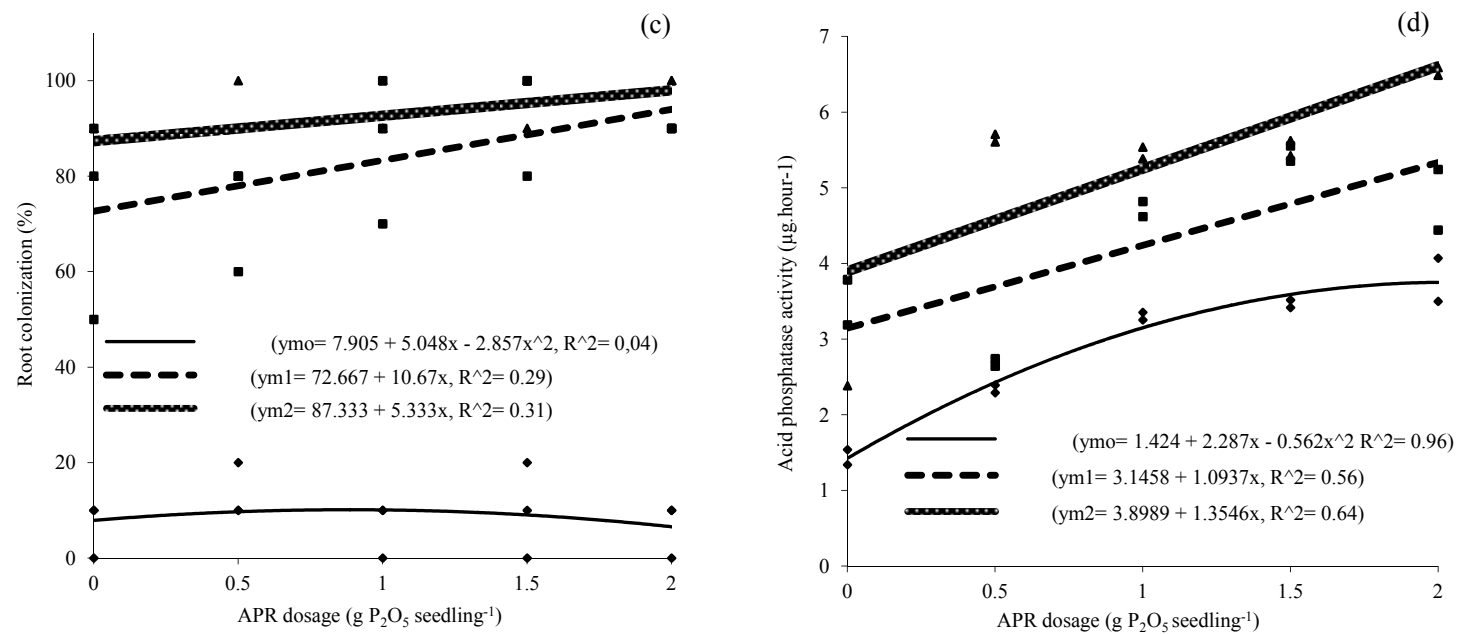

Figure 2. The relationship of Shoot dry-weight (a), shoot P uptake (b), root colonization (c), and acid phosphatase activity (d) of cocoa seedlings to APR dosage levels

Note. $\mathrm{m}_{0}=$ non AMF, $\mathrm{m}_{1}=$ Manokwari indigenous AMF, $\mathrm{m}_{2}=$ Mycofer AMF.

The interaction between AMF inoculation and APR dosage level affected leaf number, shoot dry-weight, P uptake, and root AMF colonization of cocoa seedling, whereas it affected on root AMF colonization only in the coffee seedling (Table 3; Figures 3 and 4). However, when APR dosage level was increased to $8 \mathrm{~g}$ $\mathrm{P}_{2} \mathrm{O}_{5} \cdot$ seedling ${ }^{-1}$ on coffee seedling, the level of root AMF colonization, acid phosphatase activity, leaves number, stem diameter, seedling height, shoot dry weight decreased, while P uptake had still increased. However, AMF Mycofer always produced good results in all dosage levels both on cocoa and coffee seedlings. This shows that 
effective AMF inoculation is needed to produce high quality seedlings.

Table 3. Effect of APR dosage and AMF Inoculum on leaves number, seedling height, stem diameter, shoot dry weight, root dry weight, and root-shoot ratio of coffee seedling

\begin{tabular}{|c|c|c|c|c|c|c|}
\hline Treatment & $\begin{array}{l}\text { Leaves } \\
\text { number }\end{array}$ & $\begin{array}{l}\text { Seedling height } \\
(\mathrm{cm})\end{array}$ & $\begin{array}{l}\text { Stem Diameter } \\
(\mathrm{mm})\end{array}$ & $\begin{array}{l}\text { Shoot dry weight } \\
\text { (g) }\end{array}$ & $\begin{array}{l}\text { Root dry weight } \\
\text { (g) }\end{array}$ & $\begin{array}{l}\text { Root-shoot } \\
\text { ratio }\end{array}$ \\
\hline \multicolumn{7}{|c|}{ APR dosage ( $\mathrm{g} \cdot$ seedling $\left.{ }^{-1}\right)$} \\
\hline Control: & $11.16 \mathrm{~b}$ & $13.38 \mathrm{~b}$ & $2.41 \mathrm{~b}$ & $3.74 \mathrm{~b}$ & $1.52 \mathrm{~b}$ & $344.79 \mathrm{a}$ \\
\hline 2 & $12.47 \mathrm{a}$ & $16.28 \mathrm{a}$ & $3.19 \mathrm{a}$ & $5.36 \mathrm{a}$ & $1.96 \mathrm{ab}$ & $317.94 \mathrm{a}$ \\
\hline 4 & $12.73 \mathrm{a}$ & $17.36 \mathrm{a}$ & $3.07 \mathrm{a}$ & $6.07 \mathrm{a}$ & $2.86 \mathrm{a}$ & $242.69 \mathrm{a}$ \\
\hline 6 & $12.52 \mathrm{a}$ & $16.03 \mathrm{a}$ & $3.09 \mathrm{a}$ & $5.28 \mathrm{a}$ & $2.28 \mathrm{ab}$ & $278.80 \mathrm{a}$ \\
\hline 8 & $12.48 \mathrm{a}$ & $17.50 \mathrm{a}$ & $3.13 \mathrm{a}$ & $5.98 \mathrm{a}$ & $2.56 \mathrm{ab}$ & $276.45 \mathrm{a}$ \\
\hline SP-18 (2 g.seedling $\left.{ }^{-1}\right)$ & $12.22 \mathrm{a}$ & $15.80 \mathrm{a}$ & $3.08 \mathrm{a}$ & $5.84 \mathrm{a}$ & $2.80 \mathrm{a}$ & $229.83 \mathrm{a}$ \\
\hline LSD Test (95\%) & 0.86 & 1.93 & 0.51 & 1.29 & 1.12 & 120.33 \\
\hline \multicolumn{7}{|l|}{ AMF inoculum: } \\
\hline $\mathrm{m}_{0}$ & $11.52 \mathrm{C}$ & $14.00 \mathrm{C}$ & $2.58 \mathrm{~B}$ & $3.44 \mathrm{C}$ & $1.41 \mathrm{C}$ & $304.70 \mathrm{~A}$ \\
\hline $\mathrm{m}_{1}$ & $12.32 \mathrm{~B}$ & $16.34 \mathrm{~B}$ & $3.05 \mathrm{~A}$ & $5.39 \mathrm{~B}$ & $2.24 \mathrm{~B}$ & $293.85 \mathrm{~A}$ \\
\hline $\mathrm{m}_{2}$ & $12.96 \mathrm{~A}$ & $17.82 \mathrm{~A}$ & $3.36 \mathrm{~A}$ & $7.30 \mathrm{~A}$ & $3.34 \mathrm{C}$ & $246.69 \mathrm{~A}$ \\
\hline \multicolumn{7}{|l|}{ Effectiveness (\%): } \\
\hline $\mathrm{m}_{0}$ vs $\mathrm{m}_{1}$ & 6.94 & 16.71 & 18.22 & 56.69 & 58.88 & 3.56 \\
\hline $\mathrm{m}_{0} \mathrm{vs} \mathrm{m}_{2}$ & 12.50 & 27.29 & 30.23 & 112.21 & 136.88 & 19.04 \\
\hline $\mathrm{m}_{1}$ vs $\mathrm{m}_{2}$ & 5.19 & 10.57 & 10.16 & 35.44 & 49.11 & 16.05 \\
\hline
\end{tabular}

Note. The number in each column followed by the same letter are not significantly different in LSD Test for 95\%. $\mathrm{m}_{0}=$ without $\mathrm{AMF}, \mathrm{m}_{1}=$ Indigenous AMF, $\mathrm{m}_{2}=\mathrm{AMF}$ Mycofer, $\mathrm{SP}=$ Super Phosphate, vs $=$ versus.
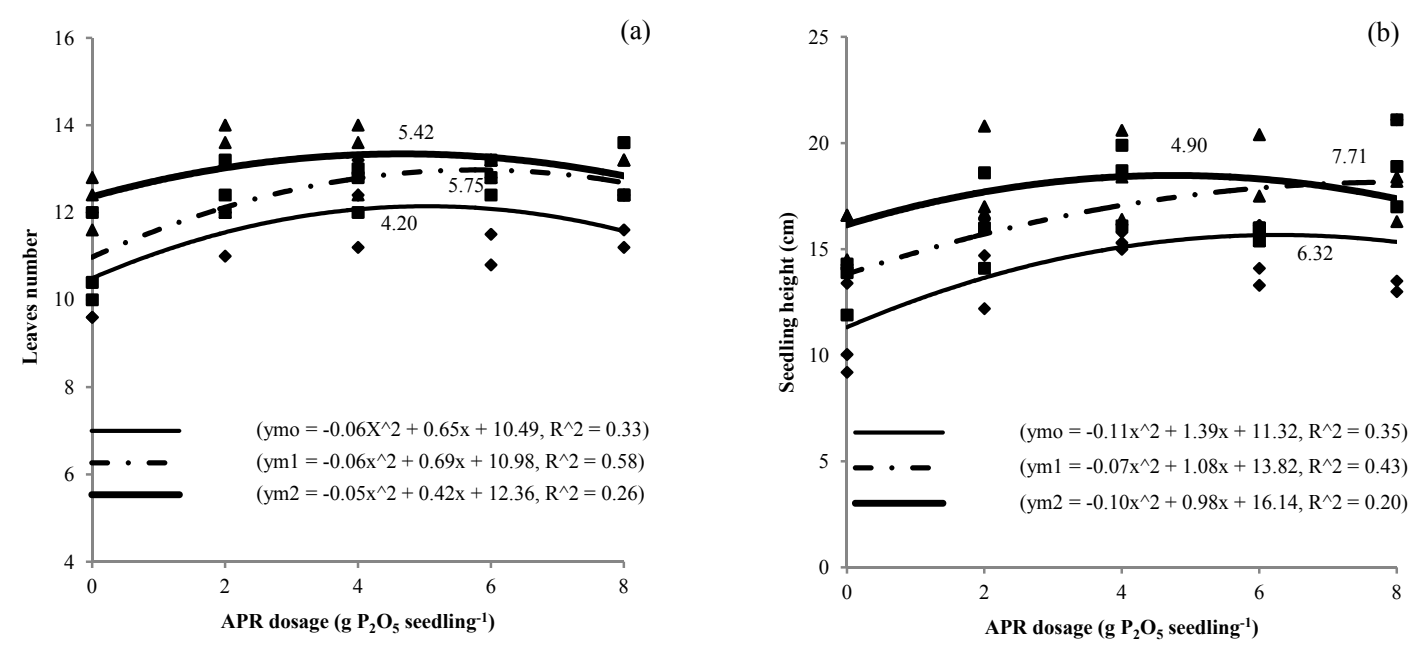

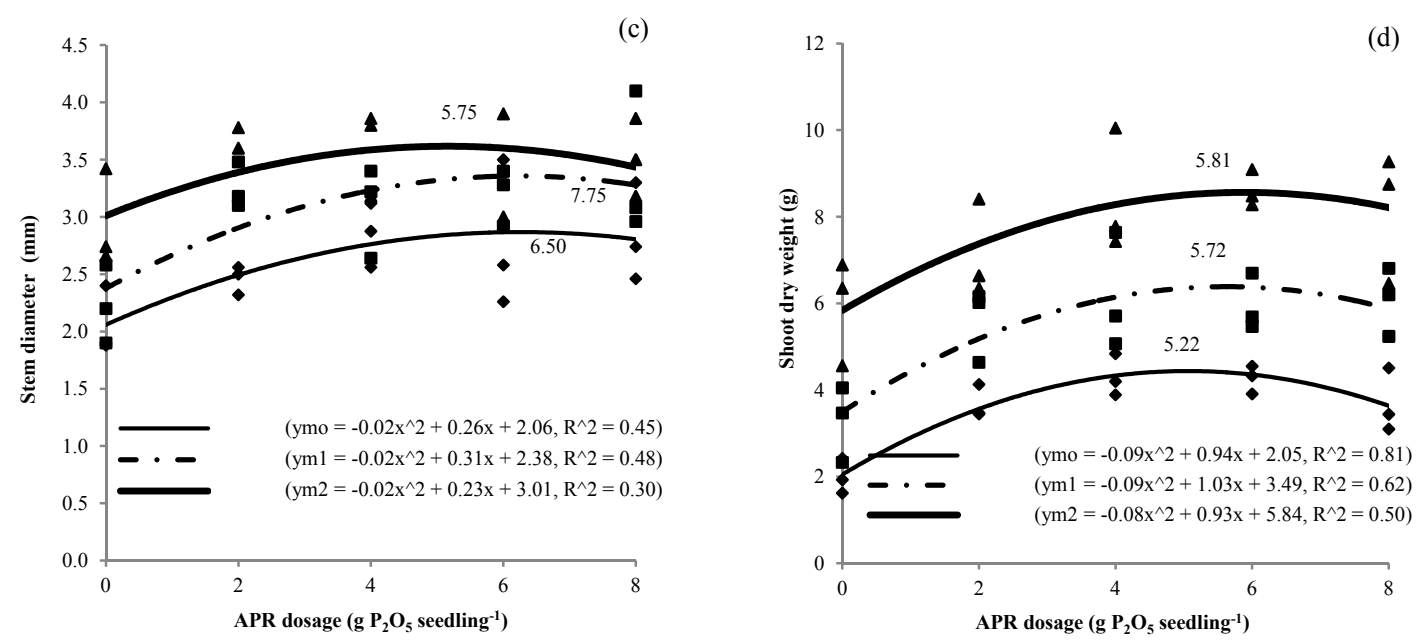

Figure 3. The interaction curve response of leave number (a), seedling height (b), stem diameter (c) shoot dry weight (d) as resulted from APR dosage levels with different AMF inoculum on coffee seedling

Note. $\mathrm{m}_{0}=$ non AMF, $\mathrm{m}_{1}=$ Indigenous AMF, $\mathrm{m}_{2}=$ Mycofer AMF.
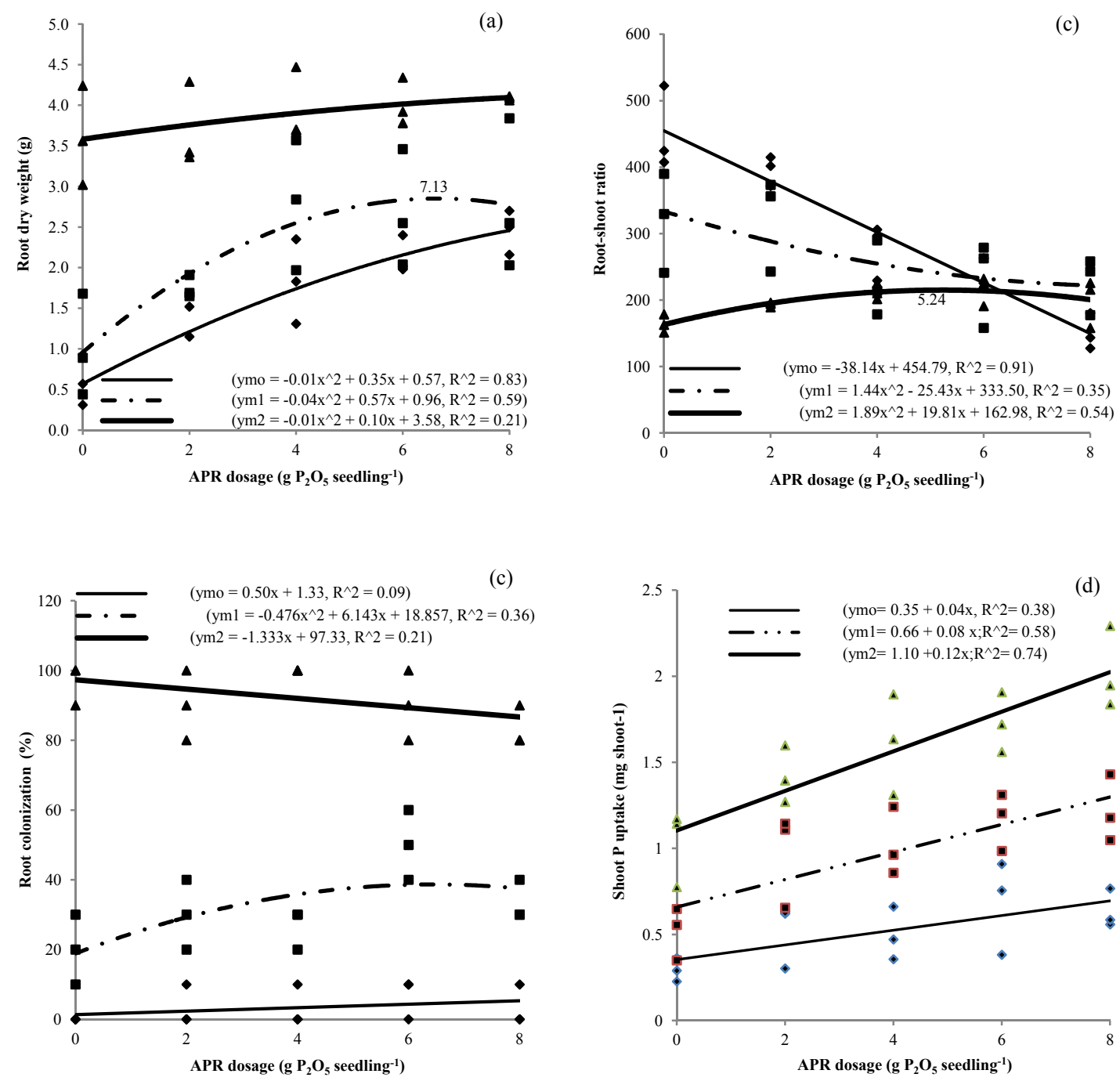


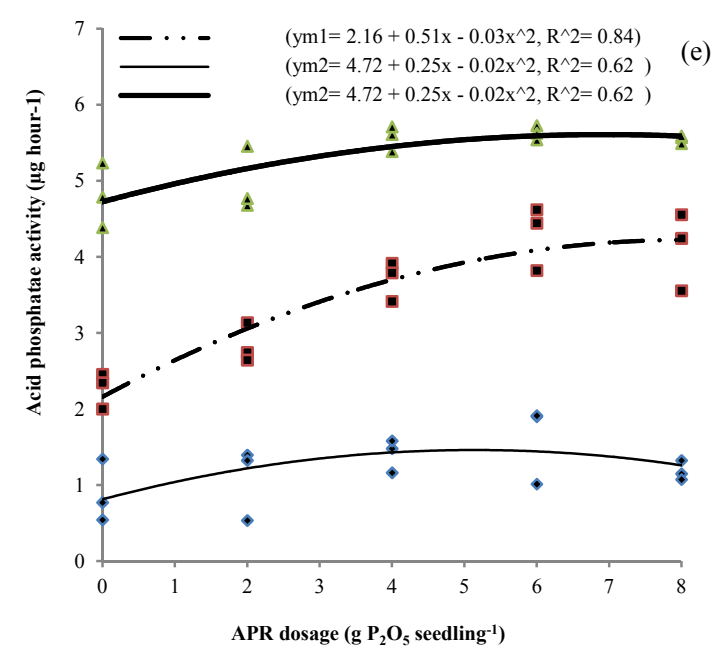

Figure 4. The interaction curve response of root dry-weight (a) root-shoot ratio (b) root colonization (c) shoot $P$ uptake (d) acid phosphatase activity (e) as resulted from APR dosage levels with different AMF inoculums on coffee seedling

Note $. \mathrm{mo}=$ non $\mathrm{AMF}, \mathrm{m}_{1}=$ Indigenous AMF, $\mathrm{m}_{2}=$ Mycofer AMF.

The utilization of low release P such as APR and bones powder even though in high dosage application, was effective to maintain AMF and to increase plant growth (Cardoso, 1996; Nikolaou et al., 2002). P content was reported to negatively correlated (Amijee et al., 1989; Koide \& Li, 1990), no correlation (Tawaraya et al., 1996), or positively correlated (Carrenho et al., 2001) with AMF, depends on AMF species, plant species, P source and its solubility (Cardoso, 1996; Tawaraya et al., 1996; Nikolaou et al., 2002; Bhadalung et al., 2005). Maximum AMF symbiotic was achieved if soil P content was not more than $50 \mathrm{mg} \cdot \mathrm{kg}^{-1}$ (50 ppm) (Ishii, 2004).

Cocoa and coffee seedling which are inoculated with AMF grew well because the AMF infected the root, intraradical hyphae (IH) and extraradical hyphae (EH) developed and spread, hence it produced positive effect on plants. The spreading of EH in soil was soon formed after root colonization. EH produce multiple function such as the transport of water and essential mineral, spore production, soil aggregation, and host plant protection from pathogen. The role of EH in essential mineral transport especially organic $\mathrm{P}$, is important because $\mathrm{EH}$ is able to reach out the depletion zone, that is unreachable and unavailable to plant roots (Zhu et al., 2001).

The contribution of AMF on water and organic P uptake was affected by AMF species, plant, and environment which indicated that the functional suitability between AMF and plant/crop is not always be related to its colonization (Pearson \& Jakobsen, 1993; Burleigh et al., 2002). AMF inoculation was done one time only, which was in planting time, but the result will be in a long time effect. This method could reduce the investment on fertilizer and pesticide supply, and therefore farmer able to produce safe agriculture products with high quality and lower in cost.

The use of AMF inoculation is proven in improving the resistance of plant to biotic and abiotic stress that result to reduce fertilizer supply and pesticide investment (Herrera et al., 1993; Douds \& Johnson, 2007; Vosatka \& Albrechtova, 2009; Koltai \& Kapulnik, 2010). The application of AMF inoculant could produce more productive plants and from stable ecosystem (van der Heijden et al., 1998; Siddiqui et al., 2008; Cameron, 2010), especially in restoring the degradation land (Herrera et al., 1993). AMF mycofer inoculant shows better effect to the growth of cocoa and coffee seedling. This is presumably because of AMF Mycofer consists of four species, and hence the benefit of each species can support one another.

Mycofer AMF is more effective because it consists of four AMF species i.e Gigaspora margarita, Acaulospora crobiculata, Glomus manihotis, and Glomus etunicatum. Positive effect of G. etunicatum could be nutrient functionality such as increasing in macro-nutrient uptake (Govindarajulu et al., 2005; Li et al., 2006), micro-nutrient (Purakayastha et al., 2001; Nogueira \& Cardoso, 2002; Andrade et al., 2010), and non-nutrient functionality such as secondary metabolic production (Yao et al., 2003; Fester \& Hause, 2007).

AMF has been reported engaged in rhizodeposition process to enrich the soil with carbon substrate with the result of the increasing of the soil biological activity (Rillig et al., 2001), and soil aggregation (Rillig et al., 2002; 
Rillig \& Mummey, 2006). Symbiosis of G. etunicatum has the impact to plant root morphology as well (Bressan \& Vasconcellos, 2002), hence it speeds up the early growing of vascular plant seedling planted at post mining area (Flores-Aylas et al., 2003; Santos et al., 2008).

Generally, plants that are symbiotic with AMF have lower shoot-root ratio than plants without AMF (Piccini et al., 1988; Khalil et al., 1994). Shoot-root ratio is the description of carbon translocation from top to the root of plants. The shoot-root ratio value get smaller due to the changing on rhizosphere dynamic that is reflected by carbon translocation to roots. And this shows one of the plant mechanisms to find out the limited nutrition. Carbon translocation to roots was showed by an increasing of root biomass, therefore it increases the root surface colonized by AMF.

The success of AMF inoculation was commonly observed based on plant indicators such as the increasing of plant dry-weight and yield dry-weight, nutrition uptake-Phosphor in particular (Rossiana \& Supriatun, 2003; Simarmata \& Herdiani, 2003). In fact, cocoa and coffee seedling inoculated with AMF always produce better growth in all of APR dosage levels.

AMF is widely known producing various benefits so the plant is capable to cope with biotic and abiotic stress (Smith \& Read, 2008; Gianinazzi et al., 2010; Smith et al., 2010). The real advantage of AMF inoculation on seedling production is in an increasing growth of seedlings when transplanted to the field. The growth of seedlings without AMF are often dwarf and leaf suffer from necrosis (Landis \& Amaranthus, 2009).

The diameter of AMF hypha is smaller than root hair, therefore it was able to reach out soil water and nutrient which were difficult to get to by plant roots. Glomus etunicatum has greater IH diameter $(2.2-18.0 \mu \mathrm{m})$, greater number of hypha and spreads all over the root, however EH developed slowly and non-extensive. $A$. tuberculata's has smaller IH diameter $(1.2-9.1 \mu \mathrm{m})$, fever hypha number but in developed faster and spread extensively on root surface (Dodd et al., 2000; Smith \& Read, 2008). Greater hypha diameter will enables greater carbon volume transported to the rhizosphere for $\mathrm{EH}$ formation and extraradical spore.

Better nutrient availability determine better growth of host plant and better establishment of AMF intra-structure (IH, vesicle, and arbuscul) and extra-structure (EH and spore) (Olsson et al., 2010). The increasing of nutrient uptake by host plants ensured to vigorous plant in order to continually supply carbon to rhizosphere (Kaschuk et al., 2010) which is needed for the formation of EH and AMF sporulation.

\section{Conclusion}

Mycofer inoculum is more effective to increase the potency of APR as fertilizer and the growth of coffee and cocoa seedling. Cocoa seedling applied with APR up to $4 \mathrm{~g} \mathrm{P}_{2} \mathrm{O}_{5}$.seedling ${ }^{-1}$ and coffee seedling applied with APR up to $8 \mathrm{~g} \mathrm{P}_{2} \mathrm{O}_{5}$. seedling ${ }^{-1}$ linearly increased the growth of both cocoa and coffee seedling. Compared to control (without AMF), inoculation of AMF Mycofer increased the cocoa seedling's height up to 50.58\% and shoot dry-weight $127.55 \%$, whereas height of coffee seedling increased by $27.29 \%$ and shoot dry-weight by $121.21 \%$. For all APR dosage, the growth of cocoa and coffee seedling inoculated with AMF Mycofer inoculum was better than inoculated by indigenous AMF and without AMF (control). This showed that AMF inoculation in both cocoa and coffee seedling increased the APR's effectiveness.

\section{Acknowledgements}

Our great gratitude goes to the Agroclimate Laboratory, Agriculture Faculty of Papua University Manokwari-Indonesia, Laboratory of Biotechnology on Forest and Environment, Research Center of Natural Resource and Biotechnology IPB, Bogor-Indonesia, the Indonesian Coffee and Cocoa Research Institute (ICCRI) Jember, Directurate General of Higher Education, and everyone who supported this research.

\section{References}

Amijee, F., Tinker, P. B., \& Stribley, D. P. (1989). The development of endomycorrhizal root systems. VII. A detailed study of effects of soil phosphorus on colonization. New Phytol., 111, 435-446. http://dx.doi.org/10.1111/j.1469-8137.1989.tb00706.x

Andrade, S. A. L., Gratão, P. L., Azevedo, R. A., Silveira, A. P. D., Schiavinato, M. A., \& Mazzafera, P. (2010). Biochemical and physiological changes in jack bean under mycorrhizal symbiosis growing in soil with

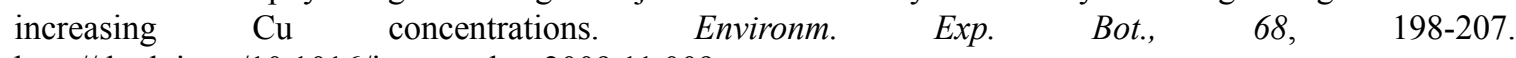
http://dx.doi.org/10.1016/j.envexpbot.2009.11.009

Bhadalung, N. N., Suwanarit, A., Dell, B., Nopamornbodi, O., Thamchaipenet, A., \& Rungchuang, J. (2005). Effects of long-term NP-fertilization on abundance and diversity of arbuscular mycorrhizal fungi under a maize cropping system. Plant Soil, 270, 371-382. http://dx.doi.org/10.1007/s11104-004-1829-4 
Bressan, W., \& Vasconcellos, C. A. (2002). Morphological alterations on root system of maize induced by mycorrhizal fungi (Glomus etunicatum and Glomus clarum) and phosphorus. Pesq. Agrope.c Brasileira, 37, 509-517. http://dx.doi.org/10.1590/S0100-204X2002000400013

Brundrett, M. C. (2009). Mycorrhizal associations and other means of nutrition of vascular plants: understanding the global diversity of host plants by resolving conflicting information and developing reliable means of diagnosis. Plant Soil, 320, 37-77. http://dx.doi.org/10.1007/s11104-008-9877-9

Burleigh, S. H., Cavagnaro, T. R., \& Jakobsen, I. (2002). Functional diversity of arbuscular mycorrhizas extends to the expression of plant genes involved in $\mathrm{P}$ nutrition. J. Exp. Bot., 53, 1593-1601. http://dx.doi.org/10.1093/jxb/erf013

Cameron, D. D. (2010). Arbuscular mycorrhizal fungi as (agro)ecosystem engineers. Plant Soil., 333, 1-5. http://dx.doi.org/10.1007/s11104-010-0361-y

Cardoso, E. J. B. N. (1996). Interaction of mycorrhiza, phosphate and manganese in soybean. In C. Azcon-Aguilar \& J. M. Barea (Eds.), Mycorrhizas in Integrated Systems from Genes to Plant Development (pp. 304-306). Proc. of the 4th European Symposium on Mycorrhiza. Brussels, Luxembourg: Directorat General XII (Science, Research and Development), European Commision. http://dx.doi.org/10.1007/s00572-011-0375-1

Carneiro, J. G. A., Barroso, D. G., \& da Silva-Soares, L. M. (2007). Growth of bare root Pinus taeda, L. seedlings cultivated under five densities in nursery. Sci. Agric. (Piracicaba, Braz.), 64, 23-29. http://dx.doi.org/10.1590/S0103-90162007000100004

Carrenho, R., Silva, E. S., Trufem, S. F. B., \& Bononi, V. L. R. (2001). Succesive cultivation of maize and agricultural practices on root colonization, number of spores and species of AM fungi. Braz. J. Microbiol., 32, 262-270. http://dx.doi.org/10.1590/S1517-83822001000400002

Dodd, J. C., Boddington, C. L., Rodriguez, A., Gonzalez-Chavez, C., \& Mansur, I. (2000). Mycelium of arbuscular mycorrhizal fungi (AMF) from different genera: form, function and detection. Plant Soil., 226, 131-151. http://dx.doi.org/10.1023/A:1026574828169

Douds, D. D., \& Johnson, Jr. N. C. (2007). Contributions of arbuscular mycorrhizas to soil biological fertility. In L. K. Abbott, \& D. V. Murphy (Eds.), Soil Biological Fertility - A Key to Sustainable Land Use in Agriculture (pp. 129-162). New York: Springer Science+Business Media.

Fester, T., \& Hause, B. (2007). Drought and symbiosis - Why is abscisic acid necessary for arbuscular mycorrhiza? New Phytol., 175, 383-386. http://dx.doi.org/10.1111/j.1469-8137.2007.02171.x

Flores-Aylas, W. W., Saggin, O. J., Siqueira, J. O., \& Davide, A. C. (2003). Effects of Glomus etunicatum and phosphorus on initial growth of woody species at direct seeding. Pesq. Agropec. Brasileira., 38, 257-266. http://dx.doi.org/10.1590/S0100-204X2003000200013

Gianinazzi, S., Gollotte, A., Binet, M. N., van Tuinen, D., Redecker, D., \& Wipf, D. (2010). Agroecology: The key role of arbuscular mycorrhizas in ecosystem services. Mycorrhiza., 20, 519-530. http://dx.doi.org/10.1007/s00572-010-0333-3

Govindarajulu, M., Pfeffer, P. E., Jin, H. R., Abubaker, J., Douds, D. D., Allen, J. W., ... Shachar-Hill, Y. (2005). Nitrogen transfer in the arbuscular mycorrhizal symbiosis. Nature, 435, 819-823. http://dx.doi.org/10.1038/nature03610

Herrera, M. A., Salamanca, P., \& Barea, J. M. (1993). Inoculation of woody legumes with selected arbuscular mycorrhizal fungi and rhizobia to recover desertified Mediterranean ecosystems. Appl. Environm. Microbiol., 59, 129-133.

Ishii, T. (2004). Vesicular-arbuscular (VA) mycorrhizae. Retrieved August 18, 2005, from http://www.bio.kpu.ac.jp/ pomlab/VAMinf.html

Kaschuk, G., Leffelaar, P. A., Giller, K. E., Alberton, O., Hungria, M., \& Kuyper, T. W. (2010). Responses of legumes to rhizobia and arbuscular mycorrhizal fungi: A meta-analysis of potential photosynthate limitation of symbioses. Soil Biol. Biochem., 42, 125-127. http://dx.doi.org/10.1016/j.soilbio.2009.10.017

Khalil, S., Loynachan, T. E., \& Tabatabai, M. A. (1994). Mycorrhizal dependency and nutrient uptake by improved and unimproved corn and soybean cultivars. Agron. J., 86, 949-958. http://dx.doi.org/10.2134/agronj1994.00021962008600060005x

Koide, R. T., \& Li, M. (1990). On host regulation of the vesicular-arbuscular mycorrhizal symbiosis. New 
Phytol., 114, 59-65. http://dx.doi.org/10.1111/j.1469-8137.1990.tb00373.x

Koltai, H., \& Kapulnik, Y. (2010). Arbuscular Mycorrhizas: Physiology and Function. Heildelberg: Springer Science-Business Media B.V. http://dx.doi.org/10.1007/978-90-481-9489-610

Landis, T. D., \& Amaranthus, M. A. (2009). Inoculate with mycorrhizae, rebuild your soil, and help stop global warming. Forest Nursery Note, 13-16.

Li, H., Smith, S. E., Holloway, R. E., Zhu, Y., \& Smith, F. A. (2006). Arbuscular mycorrhizal fungi contribute to phosphorus-fixing soil even in the absence of positive growth responses. New Phytol., 172, 536-543. http://dx.doi.org/10.1111/j.1469-8137.2006.01846.x

Miyakasa, S. C., \& Habte, M. (2001). Plant mechanisms and mycorrhizal symbioses to increase phosphorus uptake efficiency. Commun. Soil Sci. Plant Anal., 32, 1101-1147. http://dx.doi.org/10.1081/CSS-100104105

Morgan, J. A. W., Bending, G. D., \& White, P. J. (2005). Biological costs and benefits to plant-microbe interactions in the rhizosphere. J. Exp. Bot., 56, 1729-1739. http://dx.doi.org/10.1093/jxb/eri205

Nikolaou, N., Karagiannidis, N., Koundouras, S., \& Fysarakis, I. (2002). Effects of different P sources in soil on increasing growth and mineral uptake of mycorrhizal Vitis vinifera L. (cv Victoria) vines. J. Int. Sci. Vigne Vin., 36, 195-204.

Nogueira, M. A., \& Cardoso, E. J. B. N. (2002). Microbial interactions on manganese availability and uptake by soybean. Pesq. Agropec. Brasil., 37, 1605-1612. http://dx.doi.org/10.1590/S0100-204X2002001100012

Olsson, P. A., Rahm, J., \& Aliasgharzadeh, N. (2010). Carbon dynamics in mycorrhizal symbioses is linked to carbon costs and phosphorus benefits. FEMS Microbiol. Ecol., 72, 123-131. http://dx.doi.org/10.1111/j.1574-6941.2009.00833.x

Pearson, J. N., \& Jakobsen, I. (1993). Symbiotic exchange of carbon and phosphorus between cucumber and three arbuscular mycorrhizal fungi. New Phytol., 124, 481-488. http://dx.doi.org/10.1111/j.1469-8137.1993.tb03839.x

Piccini, D., Ocampa, J. A., \& Bedmar, E. J. (1988). Possible influence of Rhizobium on VA mycorrhiza metabolic activity in double symbiosis of alfalfa plants (Medicago sativa L.) grown in a pot experiment. Biol. Fertil. Soils., 6, 65-67.

Pressel, S., Bidartondo, M. I., Ligrone, R., \& Duckett, J. G. (2010). Fungal symbioses in bryophytes: new insights in the twenty first century. Phytotaxa., 9, 238-253. http://dx.doi.org/10.11646/phytotaxa.9.1.13

Purakayastha, T. J., \& Chhonkar, P. K. (2001). Influence of vesicular-arbuscular mycor-rhizal fungi (Glomus etunicatum L.) on mobilization of zinc in wetland rice (Oryza sativa L.). Biol. Fertil. Soils., 33, 323-327. http://dx.doi.org/10.1007/s003740000330

Read, D. J., Duckett, J. G., Francis, R., Ligrone, R., \& Russell, A. (2000). Symbiotic fungal associations in 'lower' land plants. Phil. Transact. Royal Soc. London (B), Biol. Sci., 355, 815-830. http://dx.doi.org/10.1098/rstb.2000.0617

Rillig, M. C., Wright, S. F., \& Eviner, V. T. (2002). The role of arbuscular mycorrhizal fungi and glomalin in soil aggregation: comparing effects of five plant species. Plant Soil., 238, 325-333. http://dx.doi.org/10.1023/A:1014483303813

Rillig, M. C., Wright, S. F., Nichols, K. A., Schmidt, W. F., \& Torn, M. S. (2001). Large contribution of arbuscular mycorrhizal fungi to soil carbon pools in tropical forest soils. Plant Soil., 233, 167-177. http://dx.doi.org/10.1023/A:1010364221169

Rillig, M. R., \& Mummey, D. L. (2006). Mycorrhizas and soil structure. Tansley Review. New Phytol., 171, 41-53. http://dx.doi.org/10.1111/j.1469-8137.2006.01750.x

Rossiana, N., \& Supriatun, T. (2003). Fitoremediasi lumpur minyak bumi dengan tanaman sengon (Paraserianthes falcataria L. Nielsen) yang diinokulasi mikoriza. In T. Simarmata, D. H. Arief, Y. Sumarni, R. Hindersah, A. Azirin \& A. M. Kalay (Eds.), Teknologi Produksi dan Pemanfaatan Inokulan Endo-Ektomikoriza untuk Pertanian, Perkebunan, dan Kehutanan (pp. 71-77). Prosiding Seminar Mikoriza, Bandung 16 September 2003. Bandung: Asosiasi Mikoriza Indonesia dan UNPAD.

Santos, J. G. D., Siqueira, J. O., \& Moreira, F. M. D. (2008). Efficiency of arbuscular mycorrhizal fungi isolated from bauxite mine spoils on seedling growth of native woody species. Rev Bras Ciencia do Solo., 32, 141-150. http://dx.doi.org/10.1590/S0100-06832008000100014 
Siddiqui, Z. A., Akhtar, M. S., \& Futai, K. (2008). Myorrhizae: Sustainable Agriculture and Forestry. Heildelberg: Springer Science-Business Media B.V.

Simarmata, T., \& Herdiani, E. (2003). Efek pemberian inokulan CMA dan pupuk kandang terhadap P tersedia, retensi P dalam tanah dan hasil bawang merah (Allium ascalonicum L.) pada Andisols. In T. Simarmata, D. H. Arief, Y. Sumarni, R. Hindersah, A. Azirin, \& A. M. Kalay (Eds.), Teknologi Produksi dan Pemanfaatan Inokulan Endo-Ektomikoriza untuk Pertanian, Perkebunan, dan Kehutanan (pp. 71-77). Prosiding Seminar Mikoriza, Bandung 16 September 2003. Bandung: Asosiasi Mikoriza Indonesia dan UNPAD.

Smith, S. E., Facelli, E., Pope, S., \& Smith, A. (2010). Plant performance in stressful environments: interpreting new and established knowledge of the roles of arbuscular mycorrhizas. Plant Soil., 326, 3-20.

Smith, S. E., \& Read, D. J. (2008). Mycorrhizal Symbiosis (3rd ed.). San Diego: Academic Press.

South, D. B. (2000). Planting morphologically improved pine seedlings to increase survival and growth. Forestry Wildlife Series., 1, 1-14.

Swift, C. E. (2004). Mycorrhiza and soil phosphorus levels (pp. 1-4). Colorado State University, Cooperation Extention. Retrieved December 19, 2005, from http://www.colostate.edu/Depts/CoopExt/TRA/PLANTS/mycorhiza.html?

Sylvia, D. M. (2005). Mycorrhizal Symbioses. Principles and Applications of Soil Microbiology (2nd ed., pp. 263-282). New Jersey: Pearson Prentice Hall, Upper Saddle River.

Tawaraya, K., Watanabe, S., Yoshida, E., \& Wagatsuma, T. (1996). Effect of onion root exudates on the hyphal growth of Gigaspora margarita. Mycorrhiza., 6, 57-59. http://dx.doi.org/10.1007/s005720050106

van den Driessche, R. (1994). Relationship between spacing in the nursery in relation to growth yield, and performance of the stock. Forest Chronicle., 60, 345-355.

van der Heijden, M. G. A., Klironomos, J. N., Ursic, M., Moutoglis, P., Streitwolf-Engel, R., Boller, T., ... Sanders, I. R. (1998). Mycorrhizal fungal diversity determines plant biodiversity, ecosystem variability and productivity. Nature, 396, 69-72. http://dx.doi.org/10.1038/23932

Vosátka, M., \& Albrechtová, J. (2009). Benefits of Arbuscular Mycorrhizal Fungi to Sustainable Crop Production. In M. S. Khan, A. Zaidi \& J. Mussarat (Eds.), Microbial Strategies for Crop Improvement (pp. 205-224). Berlin: Springer-Verlag. http://dx.doi.org/10.1007/978-3-642-01979-1_9

Wang, B., \& Qui, Y. L. (2006). Phylogenetic distribution and evolution of mycorrhizas in land plants. Mycorrhiza, 16, 299-363.

Yao, M. K., Desilets, H., Charles, M. T., Boulanger, R., \& Tweddell, R. J. (2003). Effect of mycorrhization on the accumulation of rishitin and solavetivone in potato plantlets challenged with Rhizoctonia solani. Mycorrhiza, 13, 333-336. http://dx.doi.org/10.1007/s00572-003-0267-0

Zhu, Y. G., Cavagnaro, T. R., Smith, S. E., \& Dickson, S. (2001). Backseat driving? Accessing phosphate beyond the rhizosphere-depletion zone. Trends Plant Sci., 6, 194-195. http://dx.doi.org/10.1016/S1360-1385(01)01957-4

\section{Copyrights}

Copyright for this article is retained by the author(s), with first publication rights granted to the journal.

This is an open-access article distributed under the terms and conditions of the Creative Commons Attribution license (http://creativecommons.org/licenses/by/3.0/). 